\title{
Yield of Spring Grown Chickpea (Cicer arietinum L.) under Different Doses of Soil Applied Phosphorus in An Agroecology of Semi-arid Highlands with Mediterranean Climate
}

Sipan Soysal

10.18805/LRF-642

\begin{abstract}
Background: This study was carried out to determine the effects of different phosphorus doses on the flowering, yield and yield components of spring grown chickpea crop under the ecological conditions of Siirt province in the experimental field of Siirt University, Faculty of Agriculture, Field Crops Department during two seasons in 2018 and 2019.

Methods: The study was carried out in randomized complete blocks design with three replications. Before planting, $140 \mathrm{~kg} \mathrm{ha}^{-1}$ of DAP fertilizer (18.46.0) was spreaded and incorporated into the soil with a rake. Following emergence of plants, TSP fertilizer (0.42.0) was spreaded to the plots at doses of $0,30,60,90 \mathrm{~kg} \mathrm{ha}^{-1} \mathrm{P}_{2} \mathrm{O}_{5}$ into the mellow humid soil.

Result: All observed parameters were effected from phosphorus application doses. Based on different $\mathrm{P}$ doses, two years' average plant height, first pod height; main branch number, flower number per plant, pod number per plant, grain number per plant, 100 grain weight and grain yield values were determined as $51,25-55,91 \mathrm{~cm} ; 29,17-35,98 \mathrm{~cm} ; 2,10-2,97$ piece plant $^{-1} ; 39,00-57,86$ piece $^{-1}$ plant $^{-1} ; 18,87-27,92$ piece plant $^{-1} ; 18,00-27,33$ piece plant $^{-1} ; 29,92-33,41 \mathrm{~g}$ and $969-1565 \mathrm{~kg} \mathrm{ha}^{-1}$, respectively. Highest values for all parameters were obtained from $60 \mathrm{~kg} \mathrm{ha}^{-1} \mathrm{P}_{2} \mathrm{O}_{5}$ but further dose $\left(60 \mathrm{~kg} \mathrm{ha}^{-1} \mathrm{P}_{2} \mathrm{O}_{5}\right)$ resulted with reduction from top values for all parameters.
\end{abstract}

Key words: Chickpea, Cicer arietinum L., Flower, Phosphorus, Yield.

\section{INTRODUCTION}

Pulses are important sources of vegetal proteins (Bildirici, 2020). Grains of pulses are rich in leucine, lysine, glutamic acid, aspartic acid and arginine which provide balanced amino acid profiles when mixed with cereals for consumption (Mohammed et al., 2014; Khadraji et al., 2020). They also contain essential vitamins, minerals and dietary fibre (Toğay et al., 2005; Chandra-Hioe et al., 2016; Soysal et al., 2020).

Chickpea (Cicer arietinum L.) is an economically important pulse (Gaur et al., 2011; Ramchander et al., 2020). It is a very important cool-season crop which provides nutritious food for the expanding global population and will probably become more important under changing climate conditions (Merga and Haji, 2019; Uçar and Erman, 2020). Chickpea production ranks third among pulses with an annual production of approximately 10 million tons (Muehlbauer and Sarker, 2017). It is an important legume mainly grown in rainfed areas (Deokar et al., 2011). Climate change and increasing cropping intensity force chickpea to be cultivation in higher temperature environments (Paul et al., 2018). Flowering time and crop growth duration are important traits on its adaptation to diversified climatic conditions. Early flowering and early maturing habits increase its adaptation to short seasons. In a study, days to flowering was found correlated positively with days to maturity, number of pods/plant, number of seeds/plant and seed yield/plant (Gaur et al., 2015).

High temperature and drought are major limiting factors for chickpea production and growth worldwide (Ceylan et al., 2013). This species is a heat sensitive crop and its yield
Department of Plant and Animal Production, Kurtalan Vocational High School, Siirt University, 56500, Kurtalan-Siirt, Turkey.

Corresponding Author: Sipan Soysal, Department of Plant and Animal Production, Kurtalan Vocational High School, Siirt University, 56500, Kurtalan-Siirt, Turkey. Email: sipansoysal@siirt.edu.tr

How to cite this article: Soysal, S. (2021). Yield of Spring Grown Chickpea (Cicer arietinum L.) under Different Doses of Soil Applied Phosphorus in An Agroecolog of Semi-arid Highlands with Mediterranean Climate. Legume Research. 44(11): 1328-1332. DOI: $10.18805 /$ LRF-642.

Submitted: 19-07-2021 Accepted: 27-08-2021 Online: 16-09-2021

sharply reduces under temperatures exceeding $35^{\circ} \mathrm{C}$ (Kaushal et al., 2011). Heat damages chickpea crop both at vegetative and reproductive growth stages (Kumar et al., 2012). In an experiment conducted in a temperature gradient tunnel, chickpea yield decline with increasing temperature was $6.8 \%$ per degree temperature rise (Chakrabarti et al., 2013). Chickpea as a winter crop which experiences heat stress very often during reproductive stages but plants built up diversified mechanisms to cope with heat stress (Kumar et al., 2020).

It is common to grow chickpea in semi-arid and Mediterranean regions where drought alone is responsible for up to 50\% annual yield losses (Kumar et al., 2019). Drought stress significantly reduce chickpea yields but crop adaptation to water limited condition is regulating the water supply to demand balance (Sivasakthi et al., 2018). 
Input-intensive agriculture is depleting non-renewable phosphorus reserves worldwide. This condition increased the repeated interest on efficient use of phosphorus fertilizers in crop production to enhance profitability and mitigate environmental problems related with fertilizer phosphorus application where low availability of this nutrient in soil is a main productivity limitation for crops (Venkatesh et al., 2019). Phosphorus deficiency in soils is a major factor reducing chickpea yields (Ditta et al., 2018). Low phosphorus availability in alkaline soils in arid or semi-arid regions decreases chickpea productivity (Israr et al., 2016). The efficient phosphorus management in agriculture is still a challenge with changing climate conditions (Jin et al., 2013). Phosphorus fertilization of soils is increasing the production costs and resulting with environmental harms (Rajwar et al., 2018). In a pot trial with four chickpea genotypes, with sandsoil mixture media containing low available phosphorus, plants were water-stressed or well-watered at the reproductive stage. Water stress reduced shoot growth and shoot phosphorus content for all genotypes but increased water-use efficiency (Sharma et al., 2021).

The aim of this study is to determine the change in chickpea yield and yield components under different phosphorus doses in hot (spring) semi-arid rainfed conditions in South Eastern Anatolia highland conditions where Mediterranean climate prevails.

\section{MATERIALS AND METHODS}

This study was carried out to determine the effects of different phosphorus doses on the flowering, yield and yield components of chickpea crop under the ecological conditions of Siirt province, in the experimental field of Siirt University Faculty of Agriculture Field Crops Department during two seasons in 2018 and 2019.

Azkan variety registered by a private company was used as chickpea seed in the trials. Azkan variety is an upright growing, early and drought and cold tolerant variety. The climatic data of the research location are given in Table 1.

Average temperatures during 2018 growth season were higher than the long term averages. In 2019, average temperatures were close to the long term averages. While the total amount of precipitation was similar to the long-term average in 2018, it was higher in 2019. While the average relative humidity values of 2018 were similar to the long term average, 2019 values were higher. The soils of the experimental area were high in water holding capacity, slightly alkaline, calcareous, poor in organic matter, nitrogen and phosphorus content and rich in potassium content.

Previous crop in rotation was wheat. In autumn, the trial area was machine plowed. Just before planting in the spring, cultivator and then harrow were applied to the field. Before planting, $140 \mathrm{~kg} \mathrm{ha}^{-1}$ of DAP fertilizer (18.46.0) was spreaded and incorporated into the soil with a rake. The study was carried out in randomized complete blocks design with three replications. Sowing lines were determined by a hand marker. Sowing was done by hand in the first week of
March (on dates 01.03.2018 in the first year and 03.03.2019 in the second year), with $30 \mathrm{~cm}$ interrow spacing, $5 \mathrm{~m}$ row length, 5 rows per plot and 60 plants $\mathrm{m}^{-2}$ seeding density. Distances between plots and blocks were $2 \mathrm{~m}$ and $3 \mathrm{~m}$, respectively. Following emergence of plants, TSP fertilizer (0.42.0) was spreaded to the plots at doses of $0,30,60,90$ $\mathrm{kg} \mathrm{ha-1} \mathrm{P}_{2} \mathrm{O}_{5}$ into the mellow humid soil. Research fields recieved precipitations in following days after phosphorus (P) applications in both years. Rainfed cultivation was applied without any irrigation. Weed struggle was conducted by hand. Pesticide was used for anthracnose disease. Pesticide was Antracol WP 70 (70\% propineb) and applied at a dose of $200 \mathrm{~g} / 100 \mathrm{~L}$ water. No soil cultivation was applied during crop growth. Date of flowering in the first and second years were 18.05.2018 and 21.05.2019, respectively. The flowers of the randomly selected plants in the plots were counted at full bloom stage. Before observation and harvesting, one row from the edges of the plots and $0.5 \mathrm{~m}$ from the both ends of the plots cut out. 10 plants selected from the remaining plants for observations, except grain yield parameter. Plant height, first pod height, main branch number per plant, number of pods per plant, number of seeds per plant, 100-grain weight and grain yield were investigated. For grain yield determination, parcel harvest was applied. Harvest dates for first and second years were 02.07.2018 and 04.07.2019, respectively. The plants were hand harvested and threshed in the first week of July. The data obtained as a result of the trials were analyzed in the JMP statistical package program.

\section{RESULTS AND DISCUSSION}

All parameters, except main branch number and 100 grain weight were lower in 2018 compared to 2019 (Table 2, 3 and 4). All observed parameters were effected from phosphorus $(P)$ doses. Highest values for all parameters were obtained from $60 \mathrm{~kg} \mathrm{ha}^{-1} \mathrm{P}_{2} \mathrm{O}_{5}$ but further dose $(60 \mathrm{~kg}$ $\mathrm{ha}^{-1} \mathrm{P}_{2} \mathrm{O}_{5}$ ) resulted with reduction from top values for all parameters (Table 2, 3 and 4).

Two years' average plant height values were lowest $(51,25 \mathrm{~cm})$ at control $\left(0 \mathrm{~kg} \mathrm{ha}-1 \mathrm{P}_{2} \mathrm{O}_{5}\right)$ application and highest $(55,91 \mathrm{~cm})$ at $60 \mathrm{~kg} \mathrm{ha}^{-1} \mathrm{P}_{2} \mathrm{O}_{5}$ application dose (Table 2). Average plant height values in 2018 and 2019 were 53,14 $\mathrm{cm}$ and $53,85 \mathrm{~cm}$, respectively. Two years average first pod height values were lowest $(29,17 \mathrm{~cm})$ at control $\left(0 \mathrm{~kg} \mathrm{ha}^{-1}\right.$ $\left.\mathrm{P}_{2} \mathrm{O}_{5}\right)$ application and highest $(35,98 \mathrm{~cm})$ at $60 \mathrm{~kg} \mathrm{ha}^{-1} \mathrm{P}_{2} \mathrm{O}_{5}$ application dose (Table 2). Average first pod height values in 2018 and 2019 were $31,91 \mathrm{~cm}$ and $33,51 \mathrm{~cm}$, respectively.

Averages of two years' main branch number values were lowest $\left(2,10\right.$ and 2,27 piece plant $\left.{ }^{-1}\right)$ at control $(0 \mathrm{~kg}$ ha ${ }^{-1} \mathrm{P}_{2} \mathrm{O}_{5}$ ) and $30 \mathrm{~kg} \mathrm{ha}^{-1} \mathrm{P}_{2} \mathrm{O}_{5}$ applications, respectively. This parameter was highest (2,97 piece plant $\left.^{-1}\right)$ at $60 \mathrm{~kg}$ ha $^{-1} \mathrm{P}_{2} \mathrm{O}_{5}$ application dose (Table 2). Averages of two years flower number per plant values were lowest $(39,00$ piece plant $\left.{ }^{-1}\right)$ at control $\left(0 \mathrm{~kg} \mathrm{ha}^{-1} \mathrm{P}_{2} \mathrm{O}_{5}\right)$ application and highest $\left(57,86\right.$ piece plant $\left.{ }^{-1}\right)$ at $60 \mathrm{~kg} \mathrm{ha}^{-1} \mathrm{P}_{2} \mathrm{O}_{5}$ application dose (Table 3 ). Average flower number per plant 
Yield of Spring Grown Chickpea (Cicer arietinum L.) under Different Doses of Soil Applied Phosphorus in An Agroecology of...

Table 1: Meteorogical data of the research area**.

\begin{tabular}{|c|c|c|c|c|c|c|c|c|c|}
\hline \multirow[b]{2}{*}{ Months } & \multicolumn{3}{|c|}{ Average temperature $\left({ }^{\circ} \mathrm{C}\right)$} & \multicolumn{3}{|c|}{ Total precipitation (mm) } & \multicolumn{3}{|c|}{ Average relative humidity (\%) } \\
\hline & 2018 & 2019 & $\begin{array}{l}\text { Long term } \\
\text { average* }\end{array}$ & 2018 & 2019 & $\begin{array}{l}\text { Long term } \\
\text { average* }\end{array}$ & 2018 & 2019 & $\begin{array}{l}\text { Long term } \\
\text { average* }^{*}\end{array}$ \\
\hline March & 13,7 & 8,3 & 10,1 & 47,6 & 182,0 & 92,3 & 55,9 & 63,5 & 59,2 \\
\hline April & 16,8 & 11,9 & 15,3 & 61,6 & 175,6 & 91,7 & 47,6 & 66,8 & 53,8 \\
\hline May & 19,8 & 21,9 & 20,0 & 139,6 & 64,4 & 69,5 & 59,2 & 41,8 & 49,6 \\
\hline June & 27,4 & 29,1 & 27,0 & 10,0 & 1,2 & 10,8 & 31,7 & 26,5 & 28,7 \\
\hline July & 32,3 & 30,2 & 30,6 & 0,6 & 0,0 & 2,7 & 20,1 & 23,0 & 23,3 \\
\hline Aver./Total & 22,0 & 20,3 & 20,6 & 264,8 & 423,2 & 267,0 & 42,9 & 44,3 & 42,9 \\
\hline
\end{tabular}

${ }^{\star}$ Long term average (1963-2018), ${ }^{* *}$ Turkish State Meteorological Service, Siirt Province Official Records.

Table 2: Plant height, first pod height and main branch number values determined in the study.

\begin{tabular}{|c|c|c|c|c|c|c|c|c|c|}
\hline \multirow{2}{*}{ Applications } & \multicolumn{3}{|c|}{ Plant height (cm) } & \multicolumn{3}{|c|}{ First pod height $(\mathrm{cm})$} & \multicolumn{3}{|c|}{$\begin{array}{l}\text { Main branch number } \\
\quad \text { (piece plant }^{-1} \text { ) }\end{array}$} \\
\hline & 2018 & 2019 & $\begin{array}{l}\text { Two years } \\
\text { average }\end{array}$ & 2018 & 2019 & $\begin{array}{l}\text { Two years } \\
\text { average }\end{array}$ & 2018 & 2019 & $\begin{array}{r}\text { Two years } \\
\text { average }\end{array}$ \\
\hline Control $\left(0 \mathrm{~kg} \mathrm{ha}^{-1} \mathrm{P}_{2} \mathrm{O}_{5}\right)$ & 50,37 & 52,13 & $51,25 \mathrm{D}$ & 28,23 & 30,10 & $29,17 \mathrm{D}$ & 2,07 & 2,13 & $2,10 \mathrm{C}$ \\
\hline $30 \mathrm{~kg} \mathrm{ha}^{-1} \mathrm{P}_{2} \mathrm{O}_{5}$ & 52,70 & 53,23 & $52,97 \mathrm{C}$ & 30,80 & 33,17 & $31,98 \mathrm{C}$ & 2,27 & 2,27 & $2,27 \mathrm{C}$ \\
\hline $60 \mathrm{~kg} \mathrm{ha}^{-1} \mathrm{P}_{2} \mathrm{O}_{5}$ & 56,10 & 55,72 & $55,91 \mathrm{~A}$ & 35,37 & 36,59 & $35,98 \mathrm{~A}$ & 2,93 & 3,01 & $2,97 \mathrm{~A}$ \\
\hline $90 \mathrm{~kg} \mathrm{ha}^{-1} \mathrm{P}_{2} \mathrm{O}_{5}$ & 53,40 & 54,30 & $53,85 \mathrm{~B}$ & 33,23 & 34,17 & $33,70 \mathrm{~B}$ & 2,47 & 2,53 & $2,50 \mathrm{~B}$ \\
\hline Averages & $53,14 \mathrm{~B}$ & $53,85 \mathrm{~A}$ & & $31,91 \mathrm{~B}$ & $33,51 \mathrm{~A}$ & & 2,43 & 2,49 & \\
\hline LSD, Year & & 0,629 & & & 0,627 & & & 0,137 & \\
\hline LSD, Application & & 0,854 & & & 0,854 & & & n.s. & \\
\hline LSD, Application $\times$ Year & & n.s. & & & n.s. & & & n.s. & \\
\hline
\end{tabular}

Different letters in the rows indicate significant differences according to LSD test $(P \leq 0.05)$; n.s.: non significant.

Table 3: Flower number per plant, pod number per plant and grain number per plant values determined in the study.

\begin{tabular}{|c|c|c|c|c|c|c|c|c|c|}
\hline \multirow{2}{*}{ Applications } & \multicolumn{3}{|c|}{$\begin{array}{l}\text { Flower number per plant } \\
\quad\left(\text { piece plant }{ }^{-1}\right)\end{array}$} & \multicolumn{3}{|c|}{$\begin{array}{l}\text { Pod number per plant } \\
\text { (piece plant }{ }^{-1} \text { ) }\end{array}$} & \multicolumn{3}{|c|}{$\begin{array}{l}\text { Grain number per plant } \\
\quad \text { (piece plant }^{-1} \text { ) }\end{array}$} \\
\hline & 2018 & 2019 & $\begin{array}{l}\text { Two years } \\
\text { average }\end{array}$ & 2018 & 2019 & $\begin{array}{l}\text { Two years } \\
\text { average }\end{array}$ & 2018 & 2019 & $\begin{array}{r}\text { Two years } \\
\text { average }\end{array}$ \\
\hline Control $\left(0 \mathrm{~kg} \mathrm{ha}^{-1} \mathrm{P}_{2} \mathrm{O}_{5}\right)$ & 36,00 & 39,20 & $39,00 \mathrm{D}$ & 17,80 & 19,93 & $18,87 \mathrm{D}$ & 17,00 & 19,00 & $18,00 \mathrm{D}$ \\
\hline $30 \mathrm{~kg} \mathrm{ha}^{-1} \mathrm{P}_{2} \mathrm{O}_{5}$ & 42,00 & 48,40 & $43,80 \mathrm{C}$ & 20,87 & 23,07 & $21,97 \mathrm{C}$ & 19,87 & 22,33 & $21,10 \mathrm{C}$ \\
\hline $60 \mathrm{~kg} \mathrm{ha}^{-1} \mathrm{P}_{2} \mathrm{O}_{5}$ & 54,87 & 60,86 & $57,86 \mathrm{~A}$ & 26,93 & 28,91 & $27,92 \mathrm{~A}$ & 26,27 & 28,40 & $27,33 \mathrm{~A}$ \\
\hline $90 \mathrm{~kg} \mathrm{ha}^{-1} \mathrm{P}_{2} \mathrm{O}_{5}$ & 50,07 & 54,07 & $52,07 \mathrm{~B}$ & 24,20 & 26,13 & $25,17 \mathrm{~B}$ & 23,33 & 25,47 & $24,40 \mathrm{~B}$ \\
\hline Averages & $45,0 \mathrm{~B}$ & $51,33 \mathrm{~A}$ & & $22,45 \mathrm{~B}$ & $24,51 \mathrm{~A}$ & & $21,62 \mathrm{~B}$ & $23,80 \mathrm{~A}$ & \\
\hline LSD, Year & & 1,371 & & & 0,506 & & & 0,488 & \\
\hline LSD, Application & & 1,861 & & & 0,686 & & & 0,664 & \\
\hline LSD, Application $\times$ Year & & n.s. & & & n.s. & & & n.s. & \\
\hline
\end{tabular}

Different letters in the rows indicate significant differences according to LSD test $(P \leq 0.05)$; n.s.: non significant.

values in 2018 and 2019 were 45,0 piece plant $^{-1}$ and 51,33 piece plant $^{-1}$, respectively.

Two years' average pod number per plant values were lowest $\left(18,87\right.$ piece plant $\left.{ }^{-1}\right)$ at control $\left(0 \mathrm{~kg} \mathrm{ha}^{-1}\right.$ $\left.\mathrm{P}_{2} \mathrm{O}_{5}\right)$ application and highest $\left(27,92\right.$ piece plant $\left.^{-1}\right)$ at 60 $\mathrm{kg} \mathrm{ha-1} \mathrm{P}_{2} \mathrm{O}_{5}$ application dose (Table 3). Average pod number per plant values in 2018 and 2019 were 22,45 piece plant $^{-1}$ and 24,51 piece $^{\text {plant }}{ }^{-1}$, respectively. Two years' average grain number per plant values were lowest $\left(18,00\right.$ piece plant $\left.{ }^{-1}\right)$ at control $\left(0 \mathrm{~kg} \mathrm{ha}^{-1} \mathrm{P}_{2} \mathrm{O}_{5}\right)$ application and highest $\left(27,33\right.$ piece plant $\left.{ }^{-1}\right)$ at $60 \mathrm{~kg} \mathrm{ha}^{-1} \mathrm{P}_{2} \mathrm{O}_{5}$ application dose (Table 3). Average grain number per plant values in 2018 and 2019 were 21,62 piece plant $^{-1}$ and 23,80 piece plant $^{-1}$, respectively.

Averages of two years 100 grain weight values were lowest $(29,92 \mathrm{~g})$ at control $\left(0 \mathrm{~kg} \mathrm{ha}{ }^{-1} \mathrm{P}_{2} \mathrm{O}_{5}\right)$ application and highest $(33,41 \mathrm{~g})$ at $60 \mathrm{~kg} \mathrm{ha}^{-1} \mathrm{P}_{2} \mathrm{O}_{5}$ application dose (Table 4). Averages of two years grain yield values were lowest $(969 \mathrm{~kg}$ $\left.\mathrm{ha}^{-1}\right)$ at control $\left(0 \mathrm{~kg} \mathrm{ha}^{-1} \mathrm{P}_{2} \mathrm{O}_{5}\right)$ application and highest (1565 $\mathrm{kg} \mathrm{ha}^{-1}$ ) at $60 \mathrm{~kg} / \mathrm{ha} \mathrm{P}_{2} \mathrm{O}_{5}$ application dose (Table 4). Average grain number per plant values in 2018 and 2019 were 1199 $\mathrm{kg} \mathrm{ha}^{-1}$ and $1328 \mathrm{~kg} \mathrm{ha}^{-1}$, respectively. 
Yield of Spring Grown Chickpea (Cicer arietinum L.) under Different Doses of Soil Applied Phosphorus in An Agroecology of...

Table 4: 100 grain weight and grain yield values determined in the study.

\begin{tabular}{lcccccc}
\hline \multirow{2}{*}{ Applications } & \multicolumn{3}{c}{100 grain weight $(\mathrm{g})$} & \multicolumn{3}{c}{ Grain yield $\left(\mathrm{kg} \mathrm{ha}^{-1}\right)$} \\
\cline { 2 - 7 } & 2018 & 2019 & Two years average & 2018 & 2019 & Two years average \\
\hline Control $\left(0 \mathrm{~kg} \mathrm{ha}^{-1} \mathrm{P}_{2} \mathrm{O}_{5}\right)$ & 29,90 & 29,93 & $29,92 \mathrm{D}$ & 876 & 1062 & $969 \mathrm{D}$ \\
$30 \mathrm{~kg} \mathrm{ha}^{-1} \mathrm{P}_{2} \mathrm{O}_{5}$ & 30,67 & 31,33 & $31,00 \mathrm{C}$ & 1027 & 1176 & $1102 \mathrm{C}$ \\
$60 \mathrm{~kg} \mathrm{ha}^{-1} \mathrm{P}_{2} \mathrm{O}_{5}$ & 33,17 & 33,66 & $33,41 \mathrm{~A}$ & 1505 & 1626 & $1565 \mathrm{~A}$ \\
$90 \mathrm{~kg} \mathrm{ha}^{-1} \mathrm{P}_{2} \mathrm{O}_{5}$ & 32,53 & 32,47 & $32,50 \mathrm{~B}$ & 1386 & 1446 & $1416 \mathrm{~B}$ \\
Averages & 31,57 & 31,85 & & $1199 \mathrm{~B}$ & $1328 \mathrm{~A}$ & 32,384 \\
LSD, Year & & n.s. & & 44,000 \\
LSD, Application & 0,574 & & & n.s. \\
LSD, Application $\times$ Year & n.s. &
\end{tabular}

Different letters in the rows indicate significant differences according to LSD test $(P \leq 0.05)$; n.s.: non significant.

Values for plant height, first pod height, flower number per plant, pod number per plant, grain number per plant and grain yield parameters were lower in 2018 compared to 2019 (Table 2, 3 and 4). In 2018, monthly average temperatures were higher and precipitation were lower in 2018 compared to 2019 (Table 1). Hot and drought conditions in 2018 found reflection in these yield related parameters. High temperature and drought are major limiting factors for chickpea production and growth as mentioned by Ceylan et al. (2013). Chickpea is a heat sensitive crop hence its potential yield is considerably reduced under high temperatures exceeding $35^{\circ} \mathrm{C}$ (Kaushal et al., 2011) and heat damages chickpea crop at its both vegetative and reproductive stages (Kumar et al., 2012). Chickpea is a crop commonly grown in semi-arid tropics and Mediterranean regions, its yield gets affected by abiotic stresses with drought alone being responsible for up to $50 \%$ annual loss of yield (Kumar et al., 2019). Terminal drought stress leads to substantial annual yield losses in chickpea (Sivasakthi et al., 2018).

All observed parameters were effected from phosphorus (P) application doses. Highest values for all parameters were obtained from $60 \mathrm{~kg} \mathrm{ha}^{-1} \mathrm{P}_{2} \mathrm{O}_{5}$ but further dose $\left(60 \mathrm{~kg} \mathrm{ha}^{-1}\right.$ $\mathrm{P}_{2} \mathrm{O}_{5}$ ) resulted with reduction from top values for all parameters (Table 2, 3 and 4). In a pot trial with four chickpea genotypes, with sand-soil mixture media containing low available phosphorus, plants were water-stressed or wellwatered at the reproductive stage in the study of Sharma et al. (2021) and determined that water stress reduced shoot growth of chickpeas. Phosphorus deficiency in soils is a major factor reducing chickpea yields (Ditta et al., 2018; Israr et al., 2016).

\section{CONCLUSION}

Plant available phosphorus content in soils was a major factor for chickpea yields and yield related parameters in the study. All observed parameters were effected from phosphorus doses. Highest values for all parameters were obtained from $60 \mathrm{~kg} \mathrm{ha}^{-1} \mathrm{P}_{2} \mathrm{O}_{5}$ but further dose $\left(60 \mathrm{~kg} \mathrm{ha}^{-1}\right.$ $\mathrm{P}_{2} \mathrm{O}_{5}$ ) resulted with reduction from top values for all parameters and which is a waste of resource according to the results obtained under agroecology of semi-arid highlands with Mediterranean climate in Turkey. High temperature and drought stress has a significant effect on spring grown chickpeas under this conditions.

\section{REFERENCES}

Bildirici, N. (2020). Effect of bacterial inoculation and different phosphorus doses on yield components and yield of chickpea (Cicer arietinum L.). Legume Research. 43: 446451.

Ceylan, H.A., Türkan, I. and Sekmen, A.H. (2013). Effect of coronatine on antioxidant enzyme response of chickpea roots to combination of PEG-induced osmotic stress and heat stress. Journal of Plant Growth Regulation. 32: 72-82.

Chakrabarti, B., Singh, S.D., Kumar, V., Harit, R.C. and Misra, S. (2013). Growth and yield response of wheat and chickpea crops under high temperature. Indian Journal of Plant Physiology. 18: 7-14.

Chandra-Hioe, M.V., Wong, C.H. and Arcot, J. (2016). The potential use of fermented chickpea and faba bean flour as food ingredients. Plant Foods for Human Nutrition. 71: 90-95.

Deokar, A.A., Kondawar, V., Jain, P.K., Karuppayil, S.M., Raju, N.L., Vadez, V., Varshney, R.K. and Srinivasan, R. (2011). Comparative analysis of expressed sequence tags (ESTs) between drought-tolerant and-susceptible genotypes of chickpea under terminal drought stress. BMC Plant Biology. 11: 1-20.

Ditta, A., Muhammad, J., Imtiaz, M., Mehmood, S., Qian, Z. and Tu, S. (2018). Application of rock phosphate enriched composts increases nodulation, growth and yield of chickpea. International Journal of Recycling of Organic Waste in Agriculture. 7: 33-40.

Gaur, P.M., Samineni, S., Tripathi, S., Varshney, R.K. and Gowda, C.L. (2015). Allelic relationships of flowering time genes in chickpea. Euphytica. 203: 295-308.

Gaur, R., Sethy, N.K., Choudhary, S., Shokeen, B., Gupta, V. and Bhatia, S. (2011). Advancing the STMS genomic resources for defining new locations on the intraspecific genetic linkage map of chickpea (Cicer arietinum L.). BMC Genomics. 12: 1-18.

Israr, D., Mustafa, G., Khan, K.S., Shahzad, M., Ahmad, N. and Masood, S. (2016). Interactive effects of phosphorus and Pseudomonas putida on chickpea (Cicer arietinum L.) growth, nutrient uptake, nutrient uptake, antioxidant enzymes and organic acids exudation. Plant Physiology and Biochemistry. 108: 304-312. 
Yield of Spring Grown Chickpea (Cicer arietinum L.) under Different Doses of Soil Applied Phosphorus in An Agroecology of...

Jin, J., Tang, C., Armstrong, R., Butterly, C. and Sale, P. (2013). Elevated $\mathrm{CO}_{2}$ temporally enhances phosphorus immobilization in the rhizosphere of wheat and chickpea. Plant and Soil. 368: 315-328.

Kaushal, N., Gupta, K., Bhandhari, K., Kumar, S., Thakur, P. and Nayyar, H. (2011). Proline induces heat tolerance in chickpea (Cicer arietinum L.) plants by protecting vital enzymes of carbon and antioxidative metabolism. Physiology and Molecular Biology of Plants. 17: 203-213.

Khadraji, A., Bouhadi, M. and Ghoulam, C. (2020). Effect of soil available phosphorus levels on chickpea (Cicer arietinum L.) - Rhizobia symbiotic association. Legume Research. 43: 878-883.

Kumar, M., Chauhan, A.S., Yusuf, M. A., Sanyal, I. and Chauhan, P.S. (2019). Transcriptome sequencing of chickpea (Cicer arietinum L.) genotypes for identification of droughtresponsive genes under drought stress condition. Plant Molecular Biology Reporter. 37: 186-203.

Kumar, P., Yadav, S. and Singh, M.P. (2020). Possible involvement of xanthophyll cycle pigments in heat tolerance of chickpea (Cicer arietinum L.). Physiology and Molecular Biology of Plants. 26: 1773-1785.

Kumar, S., Kaushal, N., Nayyar, H. and Gaur, P. (2012). Abscisic acid induces heat tolerance in chickpea (Cicer arietinum L.) seedlings by facilitated accumulation of osmoprotectants. Acta Physiologiae Plantarum. 34: 1651-1658.

Merga, B. and Haji, J. (2019). Economic importance of chickpea: Production, value and world trade. Cogent Food and Agriculture. 5: 1615718.

Mohammed, I., Ahmed, A.R. and Senge, B. (2014). Effects of chickpea flour on wheat pasting properties and bread making quality. Journal of Food Science and Technology. 51: 1902-1910.

Muehlbauer, F.J. and Sarker, A. (2017). Economic Importance of Chickpea: Production, Value and World Trade. In: The Chickpea Genome. Springer, Cham. (pp. 5-12).

Paul, P.J., Samineni, S., Sajja, S.B., Rathore, A., Das, R.R., Chaturvedi, S.K. and Gaur, P.M. (2018). Capturing genetic variability and selection of traits for heat tolerance in a chickpea recombinant inbred line (RIL) population under field conditions. Euphytica. 214(2): 1-14.
Rajwar, J., Chandra, R., Suyal, D.C., Tomer, S., Kumar, S. and Goel, R. (2018). Comparative phosphate solubilizing efficiency of psychrotolerant Pseudomonas jesenii MP1 and Acinetobactersp. ST02 against chickpea for sustainable hill agriculture. Biologia. 73: 793-802.

Ramchander, L., Sadhukhan, R., Das, A., Banerjee, J. and Pramanik, K. (2020). Screening for phosphorus $(P)$ acquisition efficient genotypes and identification of sequence variations among $\mathrm{p}$-efficient and inefficient genotypes in chickpea (Cicer arietinum L.). Legume Research, Online First: 18. DOI: $10.18805 /$ LR-4271.

Sharma, M., Pang, J., Wen, Z., De Borda, A., Kim, H.S., Liu, Y. and Siddique, K.H. (2021). A significant increase in rhizosheath carboxylates and greater specific root length in response to terminal drought is associated with greater relative phosphorus acquisition in chickpea. Plant and Soil. 460: 51-68.

Sivasakthi, K., Thudi, M., Tharanya, M., Kale, S.M., Kholová, J., Halime, M.H. and Vadez, V. (2018). Plant vigour QTLs co-map with an earlier reported QTL hotspot for drought tolerance while water saving QTLs map in other regions of the chickpea genome. BMC Plant Biology. 18: 1-18.

Soysal, S., Uçar, Ö. and Erman, M. (2020). The Effects of DAP (Diammoniumphosphate) fertilizer doses on grain yield and some yield properties of chickpea (Cicer arietinum L.) in the ecological conditions of Siirt province. ISPEC Journal of Agricultural Sciences. 4: 834-842.

Toğay, N., Toğay, Y., Erman, M., Doğan, Y., Çığ, F. (2005). The effects of different plant densities on yield and yield components in some chickpea (Cicer arietinum L.) cultivars in dry and irrigated conditions. Journal of Agricultural Sciences. 11: 417-421.

Uçar, Ö., Erman, M. (2020). The effects of different row spacings, chicken manure doses and seed pre-applications on the yield and yield components of chickpea (Cicer arietinum L.). ISPEC Journal of Agricultural Sciences. 4: 875-901.

Venkatesh, M.S., Hazra, K.K., Ghosh, P.K. and Mishra, J.P. (2019). Integrated phosphorus management in maize-chickpea rotation in moderately-alkaline Inceptisol in Kanpur, India: An agronomic and economic evaluation. Field Crops Research. 233: 21-32. 